\author{
Jakub Petri \\ ○ https://orcid.org/0000-0002-0584-470X \\ Department of Aesthetics, Faculty of Philosophy \\ Jagiellonian University, Kraków \\ jakub.petri@uj.edu.pl
}

\title{
THE (IN)HUMANIZATION OF TECHNOLOGY IN MODERN SILESIAN STREET ART ICONOGRAPHY: FROM THE ROSE- CROSS TRADITION TO NEW MATERIALISM?
}

\begin{abstract}
The article investigates the relationship between human beings and technology, as depicted in modern Silesian street art iconography. The author presents the esoteric worldview of the famous Janowska group of painters, based on RoseCross anthroposophy, as well as the group's connection with the contemporary Silesian street art scene represented by the artists Raspazjan and Mona Tusz. The matter of biotechnological interaction as the narration of modern Silesian street art is raised in the light of Rudolf Steiner's anthroposophical reflection on technology and its resemblance to the modern neomaterialist standpoint. Finally, a selection of murals is analyzed, as the examples of an embodied, local, materialdiscursive practice, exploring the dualism of the biotechnological world.
\end{abstract}

Keywords: street art, technology, inhuman, Janowska group, neo-materialism, Saturn

The postindustrial region of Silesia is fond of its own local street art scene which has developed a unique critical point of view concerning the matter of modern technology. Large complex structures of murals, painted by artists such as Raspazjan and Mona Tusz, can be easily found in many cities constituting the Silesian Metropolis, e.g. Katowice, Mikołów or Siemianowice Śląskie. ${ }^{1}$

1 Full documentation on the murals: http://raspazjan.blogspot.com/, https://monatusz.art. $\mathrm{pl} /$ [accessed 31.01.2020] 


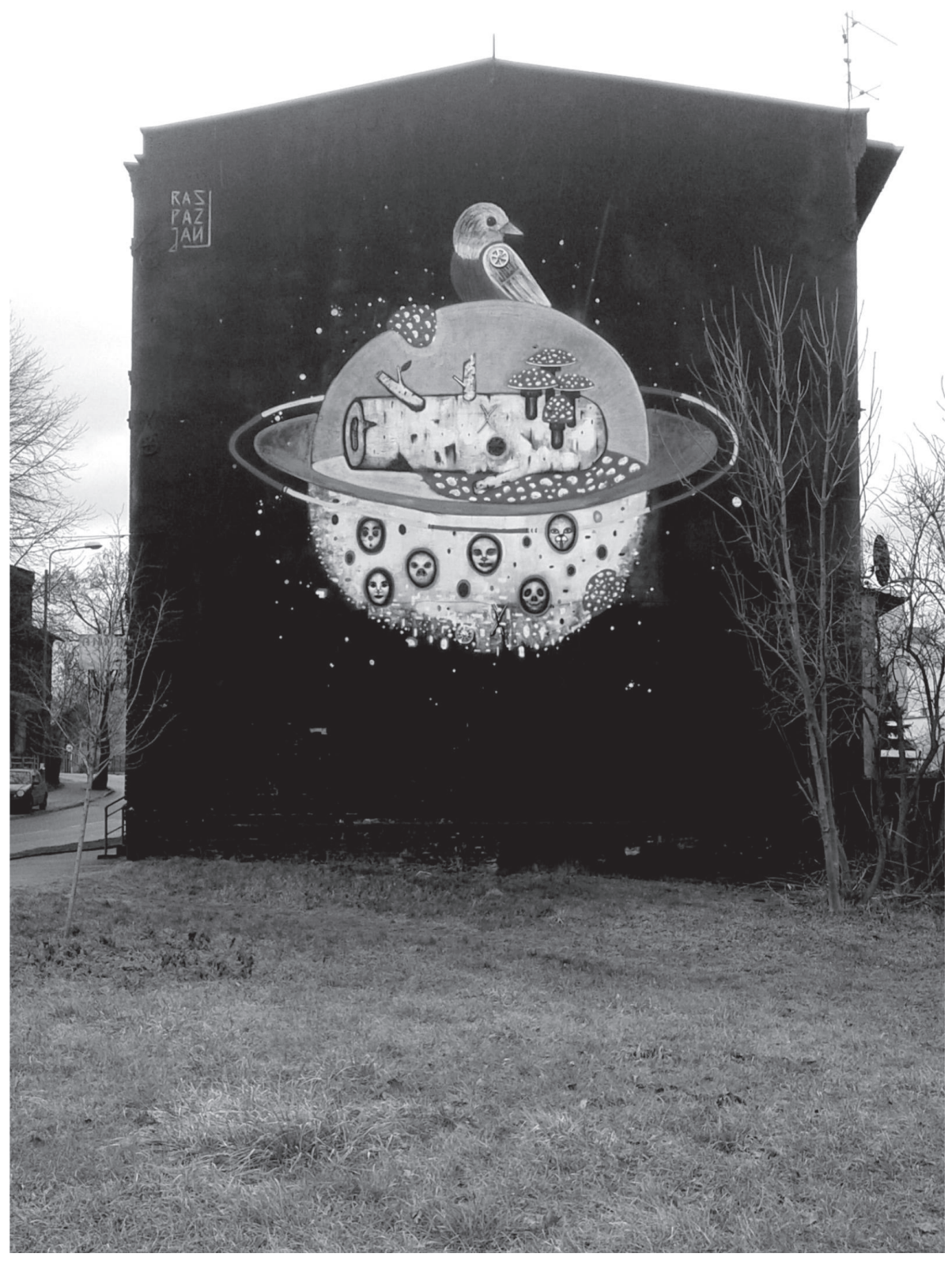

1. Katowice, Raspazjan. Source: Jakub Petri 
Taking into account some of the latest Raspazjan's creations, the viewer can notice at first glance an intriguing mix of esoteric and industrial themes incorporated into the mechanized bodies of miners, coal mine workers and endemic species of birds. A closer inspection of these images shows the presence of visual motives of the planet Saturn with its famous rings, black cubes, snake heads and ancient Egyptian masks, mixed with traditional miner emblems and complicated machines. What is the story behind these strange overscaled urban frescoes? To put some light on the symbolism of the murals and follow their hidden narration, let me set an equally symbolic starting point for further investigations - the figure of the dragon.

\section{The Dragon and its connection with the Rose-Cross movement}

While bringing the dragon onto the Silesian ground, it is important to note a famous book written by Szczepan Twardoch, entitled "Drach" - The Dragon. ${ }^{2}$ It is a crucial element of the jigsaw puzzle of facts, defining an esoteric context for the technological development of the region, which still seems to be vital for the local collective memory. The first clue is the cover of the book, a reproduction of an artwork called "Meditation", created by a Silesian esoteric painter inspired by the RoseCross movement, Erwin Sówka (Sówka 1986). The image presents a figure of a miner standing on a windowsill in a huge block of flats, accompanied by a cloud-shaped figure of a woman levitating over an estate area covered by snow. Another clue is hidden in the plot of the novel. Twardoch's Drach is the narrator, the dragon, whose body is formed of the bodies of all the characters involved in the story. Each human, animal, plant or even small stone constitutes one of the heads of the multiheaded dragon and the dragon itself constitutes the body of the Earth. What is significant, the transformation of the dragon's body during narration is connected with the passage from a natural "countryside" stage of life dominated by fluid gradient borders to the world of technology, determined by sharp geometrical divisions. In this realm, the spiritual intersects and intertwines with the physical. The author mixes two perspectives in the plot: a linear human perspective involving time and space limitations, and the dragon's non-linear pluralistic perspective which goes beyond these restrictions.

It is striking that the idea incorporated in Twardoch's book seems to reproduce the scheme of reality that originated within the RoseCross philosophical tradition. In Rudolf Steiner's anthroposophy, based on and derived from the

2 S. Twardoch, Drach, Wydawnictwo Literackie, Kraków, 2014. 
RoseCross movement mythology, reality is perceived from the perspective of a spiritual fight, symbolized by the story of St. Michael's fight with the dragon. Steiner argues that, during human evolution, the conflict was brought from the outside world into the inner reality of the human organism. ${ }^{3}$ From that moment on, the dragon has been shaping human nature, like in Twardoch's story. Since humans were cut off from their spiritual roots and concentrated on the material aspects of reality, the conflict has been internalized and each human creature is producing material space for the dragon inside themselves, thus sustaining its existence. However, it is considered as part of the natural process of human transformation and these so-called Arhimanic (material) impulses must be accommodated and transcended:

"[Today] we live among the hustle and bustle of the present age, and we can certainly say that mechanized life has also spread everywhere. Fundamentally speaking, we are always within the mechanized life of the present age. When asleep, the soul merges into everything that is mechanism. Those are mechanisms, however, that we have constructed ourselves. A mechanism we have built is something quite different from nature outside us, for this has been constructed by elemental spirits [...] What are we doing when we take things from nature and put them together to make the machines and appliances we use in our lives?"

When analysed from the perspective of more than one hundred years of constant technological development, the story can be perceived as an extremely inspiring attempt to grasp the transactional and transforming role of technology in the context of human identity and subjectivity. The abovementioned processes of materialization and internalization of some external phenomena, which in earlier magical and religious paradigms were associated with powerful inhuman forces ruling the world, make it possible for us to interpret technology as a sphere of interaction between what is biological and mechanical. It is striking that, in spite of the fact that we use the traditional dualistic categories of subject and object, or spirit and body on the operational level, Steiner claims that the described forms of interactions between biological bodies and mechanical entities lead to the evolution of the whole humankind towards overcoming the experienced dualism. This, however, results from a radical monist standpoint which constitutes the basis for Steiner's anthroposophy:

"Monism refuses to infer in an abstract way that the ultimate causes of the world that is presented to our perceiving and thinking are to be found in

3 R. Steiner, The Destinies of Individuals and of Nations, The Nature of the Christ Impulse and the Michaelic Spirit Serving It, 1915, https://wn.rsarchive.org/Lectures/Dates/19150117p01. html [accessed 30.05.2020]

4 Ibidem 
a region outside this world. For monism, the unity that thoughtful observation - which we can experience - brings to the manifold multiplicity of percepts is the same unity that man's need for knowledge demands, and through which it seeks entry into the physical and spiritual regions of the world. Whoever seeks another unity behind this one only proves that he does not recognize the identity of what is discovered by thinking and what is demanded by the urge for knowledge. The single human individual is not actually cut off from the universe. He is a part of it, and between this part and the totality of the cosmos there exists a real connection which is broken only for our perception. At first we take this part of the universe as something existing on its own, because we do not see the belts and ropes by which the fundamental forces of the cosmos keep the wheel of our life revolving." 5

It is worth noting that the consequences of monism described by Steiner are extremely close to "thing power", a category proposed by Jane Bennet in the $21^{\text {st }}$ century (Bennet, 2004). Bennet also notes very close relationships between bodies and structures traditionally defined as "dead" or nonorganic. She starts her fundamental book, "Vibrant Matter. A Political Ecology of Things", with a radical critique of the dual division of matter into active, living, organic forms and non-active "material" structures of reality:

"The quarantines of matter and life encourage us to ignore the vitality of matter and the lively powers of material formations, such as the way omega-3 fatty acids can alter human moods or the way our trash is not "away" in landfills but generating lively streams of chemicals and volatile winds of methane as we speak. I will turn the figures of "life" and "matter" around and around, worrying them until they start to seem strange, in something like the way a common word when repeated can become foreign, nonsense sound. In the space created by this estrangement, a vital materiality can start to take shape."

Steiner, in a similar manner, points out the significance of interactions between humans and material impulses, and entities coming from the "external" world:

"We are in that case not merely putting together physical components, for in putting together physical components we always provide opportunity for a demonic Ahrimanic servant to unite with the machine. We do this with every machine, every mechanism, in everything of this kind that is a part of modern civilization [...] And living surrounded by machines, we live together with these demonic Ahrimanic elementals. We allow them to enter into us; we allow not

5 R. Steiner, The Philosophy of Freedom, The Consequences of Monism, 1918 https://wn.rsarchive.org/Books/GA004/English/RSP1964/GA004_conmon.html [accessed 30.05.2020]

6 J. Bennet, Vibrant Matter. A Political Ecology of Things, Duke University Press, 2010, p. 7. 
only squealing and groaning of machines to enter into us, but also an element that is eminently destructive for our spirit and our soul."7

It is important to remember here that the described situation is understood by Steiner as a necessity, as those destructive relations with inhuman entities finally lead to the improvement of cognition and transformation of human bodies. It is striking that this kind of reflection has been developed at present times by another neomaterialist philosopher - Karen Barad. What is more, the Baradian notion of the "inhuman" is characterized by very similar tension founded on the intimate and difficult process of touching of the entities which are trespassing the thresholds of human perception. ${ }^{8}$ This standpoint seems to be strictly correlated with an extremely relational intraactive concept of emergent subjectivity proposed by Barad. She points out the role of what she calls the "inhuman" aspect of human cognition:

"The inhuman is not the same as the nonhuman. To my mind, these terms speak to very different questions and different differences. While the "nonhuman" is differentially (co)constituted (together with the "human") through particular cuts, I think of the inhuman as an infinite intimacy that touches the very nature of touch, that which holds open the space of the liveliness of indeterminacies that bleed through the cuts and inhabit the between of particular entanglements." 9

As it can be seen, both abovementioned cognitive situations generate a difficult sphere of transition, going far beyond the human comfort zone based on repeatable schemes of cultural representation. In fact, both the posthuman perspective of neomaterialists such as Karen Barad and Steiner's perspective on the human-technological transformation, are concentrated on enhancing the human ability to sense and interact with the world. According to anthroposophy and its cosmology, a way out of the current "human" situation is to experience the previous conditions or state of reality (called "the Old Saturn") from a new perspective, and to re-integrate those conditions through human experience. It is perceived as possible, as the previous state is believed to be embodied in the present Earth reality. The Old Saturn reality, determined by warmth and no space and time limitations, is understood similarly to Twardoch's "Drach" state described in the novel. So, to experience Old Saturn conditions

7 R. Steiner, The Destinies of Individuals and of Nations, The Nature of the Christ Impulse and the Michaelic Spirit Serving It, 1915, https://wn.rsarchive.org/Lectures/Dates/19150117p01. $\mathrm{html}$ [accessed 30.05.2020]

8 K. Barad, On Touching - The Inhuman That Therefore I Am, v1.1, https://www.diaphanes. net/titel/on-touching-the-inhuman-that-therefore-i-am-v1-1-3075 [accessed 30.01.2020]

9 K. Barad, Intra-actions, an interview with Karen Barad, 2012, p. 81, https://es.scribd.com/ document/342381833/Intra-Actions-Interview-of-Karen-Barad [accessed 30.01.2002] 
is to experience the "Drach" nature and thus reality beyond time and space limitations. From this perspective, technology, industry and machines connect us with other forms of existence and produce techno-human assemblages, which results in the melting of traditional forms of subjectivity, but also in the simultaneous enhancement of human cognition. This is recognized by Steiner as part of the process of the spiritual transformation of the self.

\section{The Janowska Group}

Surprisingly, the point of view presented by Twardoch in his novel and its Ross-Cross origins are not so unknown within the Silesian artistic tradition, as they are widely associated with an amateur group of esoteric painters called the Janowska Group, which was active from before WW2 to the 1950s. Miner Teofil Ociepka is the most recognized member of the group, as he was its leader known from a famous prophecy, according to which a deadly ray blasted from Saturn would destroy the house of the Silesian Parliament and, after that, the whole Earth. Ociepka was familiar with Rose-Cross teachings, as he was a member of the Rose-Cross lodge, after being introduced to it by his spiritual teacher, Filip Hofmann from Wittenberg. During his career, he put pressure on other painters from the group to preserve the inherited esoteric tradition in their works. One of Ociepka's talented colleagues, Erwin Sówka, the only living member of the group, is considered by the already mentioned muralist Raspazjan as his teacher and master. Following the esoteric pattern of the original group, Sówka creates incredible mystical paintings, depicting processes of the technological transformation of the biological world. On his canvas, we can clearly distinguish a triad of repeating elements: the human body / technology / the supernatural world. His pictures very often depict the process of the mechanical production of human bodies (Sówka, Technological Progress, 1981), relationships between planets (especially Saturn) and male/female bodies (Sówka, Illusion of Gaia, 2011) or processes, such as the cycle of birth and death in relation to the planetary cycle and bioengineering (Sówka, The Great Mother Within the Ocean of the Universe, 2011).

Not surprisingly, Sówka seems to be both an unconscious and direct inspiration for Raspazjan and Mona Tusz, a couple of renowned Silesian street artists. Unconscious, as he draws on Silesian urban legends about supernatural events taking place in very common, random locations of old workers' colonies, coal mines or ironworks. These stories and pictures create a sphere of shared experience for Silesians, and are widely recognized thanks to works created by painters such as Sówka, but also writers such as Szczepan Twardoch or Małgorzata Szejnert, or film makers - e.g. Kazimierz Kutz. However, Sówka is also a direct inspiration for Raspazjan (and partially for Tusz), as these two 
artists often works together. Raspazjan considers himself as a direct apprentice to Sówka. The cooperation even resulted in a joint exhibition of paintings: Sów$\mathrm{ka} /$ Raspazjan in Katowice (2018). ${ }^{10}$

\section{Street art as part of the materialdiscursive practices of human transformation}

Agnieszka Gralińska-Toborek defines street art as a form of intuitive practice or even as "art without theory". ${ }^{11}$ Indeed, modern street art seems to be far more contextual than it was expected before and it also appears to be a highly interactive form of urban activity breaking the linguistic and semiotic understanding of image in culture. ${ }^{12}$ Researchers also point out the aspect of the inevitability of aesthetic experience in relation to street art practice. ${ }^{13}$ It seems that the process is reshaped against the Silesian background by strong tension built up on the industrialization / deindustrialization and nature / technology dualisms. ${ }^{14}$ In this respect, street art can be measured due to its "response-ability", understood in the already mentioned Baradian mood as a form of contact, "being in touch" with other entities involved in the entanglement. ${ }^{15}$ So, the imaginary created by artists such as Raspazjan or Mona Tusz, belongs to the domain of materialdiscursive practices of the rapid transformation that started taking place in Silesia in the last century and is still going on. Choosing from many artworks of the abovementioned artists, I would like to refer to three extremely interesting creations, due to their importance for the field of relationships between human beings and technology.

\section{Human and the machine}

The first group of artworks is a collection of murals by Raspazjan and Tusz, painted in the city of Czeladź on the walls of an abandoned coal mine and the power plant "Saturn" built by investors from the city of Łódź, Alfred Bie-

10 More on the exhibition: https://katowice.wyborcza.pl/katowice/7,35018,24250641,mistrzerwin-i-jego-uczen-tajemnicza-wystawa.html [accessed 31.06.2020]

11 A. Gralińska-Toborek, Graffiti i Street art. Stowo, obraz, działanie, Wydawnictwo Uniwersytetu Łódzkiego, 2019, p. 16, 20.

12 A. Gralińska-Toborek, op cit, 2019, p. 149.

13 A. Gralińska-Toborek, W. Kazimierska-Jerzyk, Doświadczenie sztuki w przestrzeni miejskiej. Galeria Urban Forms 2011-2013, Urban Forms, Łódź, 2013, p. 33.

14 J. Petri, The Garden Cities of Katowice: A Study of Cityholia, Art Inquiry, vol. 18, pp. 127-143, J. Petri, Under construction: urban practices of terrain vague in Upper Silesia, Acta Universitatis Lodziensis. Folia Philosophica, vol. 33, pp. 65-74.

15 K. Barad, On Touching - The Inhuman That Therefore I Am, v1.1, https://www.diaphanes.net/titel/on-touching-the-inhuman-that-therefore-i-am-v1-1-3075 [accessed 30.05.2020] 
dermann and Karol Scheibler, at the end of the $19^{\text {th }}$ century. The murals, which are now partially destroyed, can be described as a personification of a coal mine, as they depict coal mine machinery being enacted and animated by male and female figures involved in the maintenance of the system. The presence of Saturn symbolism is extremely visible. The main figure is holding the planet with its rings directly on her knees. Other murals are framed with lines including smaller Saturn symbols in their axes. The experience of the murals can be expressed in the categories of immersion, as viewers are stimulated by the mix of human and machine features in a way which is appealing to their proprioceptive projections of the body. ${ }^{16}$

\section{Human and (re)production}

Another interesting mural experience is associated with an artwork by Mona Tusz, located in the city of Siemianowice Ślaskie in the Park of Tradition. The large-scale horizontal mural, made using paint and the mosaic technique, depicts a production line controlled by male and female workers. The workers are producing small pieces of glass reflecting details of the surroundings, as well as the images of viewers. Moving along the mural, one can enjoy seeing his or her own changing image which disappears and appears during the walk. The process evokes the experience of being attached to the production line and also the impression of fragility of one's existence. A trained eye will notice small Saturn symbols hidden in the mural background.

\section{Human and ecology}

Last but not least, there is a mural depicting the planet Saturn itself, made by Raspazjan. The huge image, occupying the entire wall of a building, is located in the centre of the city of Katowice, close to the International Congress Centre "Spodek" where the $24^{\text {th }}$ Conference of the Parties to the United Nations Framework Convention on Climate Change took place in 2018. The mural was commissioned by the authorities on the occasion of the conference and it was intended to project an optimistic message on climate. Instead, Raspazjan created a dark and gloomy picture of the revolving planet Saturn which, according to the words of the artist, "is preparing to blast a deadly ray towards the Earth". ${ }^{17}$ The ecological warning is a direct reference to the famous prophecy of Teofil

16 M. Paterson, More-than Visual Approaches to Architecture. Vision, Touch, Technique, Social and Cultural Geography, vol. 12, 2011, pp. 263-281.

17 https://katowice.naszemiasto.pl/mural-raspazjana-na-scianie-kamienicy-w-dabrowce-malej/ ar/c13-4819653 [accessed 30.06.2020] 
Ociepka and provides the best summary of the materialdiscursive practice of the modern human relationship with technology: if we do not transform ourselves, we shall perish.

\section{Summary}

The power of street art lies in its diversity and vitality. Ten years after Banksy announced the final fall of street art, due to its conformism and entanglement into the corrupted global art system, we can still observe some spontaneous and unobvious artworks popping up all around the world. ${ }^{18}$ There is an interesting trend that I refer to as "localism" - activity taking place far away from the reality of global site-specific artistic transfers focused on "producing" street art images on demand of the cultural policy of municipal authorities. Localism is rather based on performative "firsthand" knowledge acquired during long-term processes of participation in local communities. This is a kind of embodied knowledge inherited in ways of thinking, acting and physical habits. In this paradigm, an urban artist not only creates images, but establishes acts of material practice reshaping his or her own environment. So, the narration of art is not a matter of some kind of an external idea, but of repetitive material practices. In this case, the discourse of art can be understood as the process of redeveloping the tactics of "response-ability" to adjust them to local conditions. On the one hand, the process is defined by its historical, biological and technological trajectory, but on the other hand it is always open to innovation. The power of art lies neither in the quality of the image itself, nor in the ability to establish formal relationships with the urban context, but rather depends on affect which is understood as intensity by Brian Massumi and precedes rationalization. To tell the difference better, there are famous street artists such as DaLeast, Blu or Aryz, whose artworks will generally fit any urban space on the globe and impress most audiences, but there are also muralists like Mona Tusz and Raspazjan, whose creations constitute an integral part of the local "backyard". The backyard has grown into its citizens and transformed their tastes to such an extent that it is unthinkable for the artworks they produce to exist in a different location.

18 Banksy, Exit Through the Gift Shop, movie, Revolver Entertainment, 2012. 


\section{BIBLIOGRAPHY:}

Banksy (2012), Exit Through the Gift Shop, movie, Revolver Entertainment.

Barad, Karen (2012a), On Touching - The Inhuman That Therefore I Am, v1.1, https://www.diaphanes.net/titel/on-touching-the-inhuman-that-therefore-i-am-v1-1-3075 [accessed 30.05.2020]

Barad Karen (2012b), Intra-actions, an interview with Karen Barad, https://es.scribd.com/document/342381833/Intra-Actions-Interview-of-Karen-Barad [accessed 30.05.2002]

Bennet Jane (2004), The Force of Things: Steps Toward an Ecology of Matter, Political Theory, Vol. 32, No. 3 (Jun., 2004), pp. 347-372.

Bennet Jane (2010), Vibrant Matter. A Political Ecology of Things, Duke University Press.

Gralińska-Toborek Agnieszka (2019), Graffiti i Street art. Stowo, obraz, działanie, Wydawnictwo Uniwersytetu Łódzkiego.

Gralińska-Toborek Agnieszka, Jerzyk, Kazimierska-Jerzyk Wioletta (2013), Doświadczenie sztuki w przestrzeni miejskiej. Galeria Urban Forms 2011-2013, Urban Forms, Łódź, 2013.

Paterson Mark (2011), More-than Visual Approaches to Architecture. Vision, Touch, Technique, Social and Cultural Geography, vol. 12, pp. 263-281.

Petri Jakub (2016), The Garden Cities of Katowice: A Study of Cityholia, Art Inquiry, vol. 18, pp. 127-143.

Petri Jakub (2019), Under construction : urban practices of terrain vague in Upper Silesia, Acta Universitatis Lodziensis. Folia Philosophica, vol. 33, pp. 65-74.

Steiner Rudolph (1915), The Destinies of Individuals and of Nations, The Nature of the Christ Impulse and the Michaelic Spirit Serving It, https://wn.rsarchive.org/Lectures/Dates/19150117p01. html [accessed 30.05.2020]

Steiner Rudolf (1918), The Philosophy of Freedom, The Consequences of Monism, https://wn.rsarchive.org/Books/GA004/English/RSP1964/GA004_conmon.html [accessed 30.05.2020

Twardoch Szczepan (2014), Drach, Wydawnictwo Literackie, Kraków

\section{(NIE)LUDZKA TECHNOLOGIA W IKONOGRAFII WSPÓŁCZE- SNEGO ŚLASKIEGO STREET ARTU (streszczenie)}

Artykuł poświęcony jest zagadnieniu ikonografii współczesnego śląskiego street artu w kontekście relacji człowiek - technologia. Autor, odwołując się do światopoglądu ezoterycznego ruchu Różo - Krzyża, wskazuje na jego wpływ na twórczość współczesnych śląskich artystów 
miejskich, Raspazjana oraz Mony Tusz, z uwzględnieniem pośrednictwa malarzy Grupy Janowskiej. Podniesiona zostaje kwestia relacji pomiędzy światem natury a technologii w kontekście antropozoficznych poglądów Rudolfa Steinera oraz współczesnej filozofii nowego materializmu. Autor poddaje analizie wybór murali, wskazując na ich funkcję jako rodzaju praktyk materialno - dyskursywnych, które nakierowane są na eksplorację dualizmów bio-technologicznego świata.

Słowa kluczowe: street art, technologia, nieludzkie, Grupa Janowska, nowy materializm, Saturn

Jakub Petri - PhD, works at the Department of Aesthetics of the Jagiellonian University, Cracow, Poland. He specializes in urban aesthetics, somaesthetics and transcultural studies. He is the author of a book on Japanese urban space (Estetyczne aspekty japońskiej przestrzeni miejskiej, 2009) and several articles on the aesthetics of street art and performative urban disciplines. He was also the editor of the volume of proceedings of the 19th International Congress of Aesthetics (ICA) (Performing Cultures, 2016) and organized a conference on the aesthetics of urban space ("Estetyczne Aktywacje Przestrzeni Miejskiej”, Cracow 2015). 